\title{
NON-DESTRUCTIVE EVALUATION OF THE LEAF AREA OF GARLIC CROP USING MATHEMATICAL MODELS
}

\author{
AVALIAÇÃO NÃO-DESTRUTIVA DE ÁREA FOLIAR DA CULTURA DO ALHO \\ ATRAVÉS DE MODELOS MATEMÁTICOS
}

\author{
Felipe Augusto Reis Gonçalves ${ }^{1}$; Macelo de Paula SENOSKI ${ }^{2}$; Thiago Picinatti RAPOSO ${ }^{3}$; \\ Leonardo Angelo de AQUINO ${ }^{4}$; Maria Elisa de Sena FERNANDES ${ }^{5}$ \\ 1. Engenheiro Agrônomo, Mestre pelo Programa de Pós-Graduação em Agronomia - Produção Vegetal, da Universidade Federal de \\ Viçosa - Campus Rio Paranaíba. felipe.a.agro@gmail.com; 2. Engenheiro Agrônomo pela Universidade Federal de Viçosa - Campus \\ Rio Paranaíba; 3. Engenheiro Agrônomo, Mestre pelo Programa de Pós-Graduação em Agronomia - Produção Vegetal, da Universidade \\ Federal de Viçosa - Campus Rio Paranaíba; 4. Engenheiro Agrônomo, Docente do Programa de Pós-Graduação em Agronomia - \\ Produção Vegetal, da Universidade Federal de Viçosa - Campus Rio Paranaíba. 5. Engenheira Agrônoma, Docente do Programa de \\ Pós-Graduação em Agronomia - Produção Vegetal, da Universidade Federal de Viçosa - Campus Rio Paranaíba.
}

\begin{abstract}
Growth measurements such as leaf area (LA) and dry matter (DM) are important in experiments about plants population, fertilization, irrigation and others parameters of cultivation, in garlic crop. The LA and DM are commonly defined as destructive, lengthy and cause loss of plants in the experimental units. The objective of this study was to fit mathematical models using linear models that estimate the leaf area and dry matter of garlic plants - variety Ito. For that, garlic plants were collected at 30, 45, 60, 75, 90, 115 and 120 days after planting. The measurements of width (W), length (L) of leaves, LA, DM, pseudostem diameter (PD), number of leaves per plant $(\mathrm{NL})$ and height $(\mathrm{H})$ were determined in each time. The models were fitted to estimate the LA or DM as function of the variables W, L, L*W, PD and LA. The statistical analysis of the linear regression, coefficient of determination of the linear regression $\left(\mathrm{R}^{2}\right)$, root mean square error (RMSE), modified concordance index (d1) and the BIAS index were verified to determine the most representative models. It's possible to estimate the LA and the leaf DM of garlic plants using the variables: length, width, pseudostem diameter and height of plants.
\end{abstract}

KEYWORDS: Allium sativum L.. Alometry. Growth

\section{INTRODUCTION}

Garlic (Allium sativum L.) is a vegetable crop used for food or medicinal purposes. Brazil is a major producer and consumer of garlic. Minas Gerais state has one of the biggest national productions. The Alto Paranaiba region highlights for the cultivation of noble varieties such as variety Ito (ANAPA, 2016).

Brazil produces only the third part of the consumed garlic, but it can become self-sufficient in production. For this, efficient strategies of management and choice of appropriate varieties by region (OLIVEIRA et al., 2010), adjustment on population density (MORAVČEVIĆ et al., 2011) and fertilization according to the crop requirements (CUNHA et al., 2015). The nutrient requirements characterization, peculiarities in the management and morphological aspects are essential to achieve high quality and productivity (REZENDE et al., 2013; CUNHA et al., 2015).

The leaf area (LA) determination can be used to measure the crop growth rate during their cycle and the effect of different management strategies adopted. The leaf area can be used to assess the photosynthetic efficiency, dry matter accumulation, as well to detect biotic and abiotic stress and nutritional deficiency (BUSATO et al., 2010). The width, leaf length and LA may be directly related to the production of bulbs, according to Rezende et al. (2013).

The leaf area can be used to calculate several growth indices, such as leaf area index, net assimilation rate, specific leaf area, specific leaf weight and leaf length (MOKHTARPOUR et al., 2010; JADOSKI et al., 2012; NGUY-ROBERTSON et al., 2012). The DM is another important factor for evaluating the plant growth. The LA and DM determinations may be performed by direct or indirect methods. The most desired methods are those that are easy to perform, present low cost, do not need specialized work and can be performed with good accuracy in the field (RAMOS et al., 2008).

The direct method is destructive, therefore, it's necessary to withdraw leaves for measurement in specific instruments in order to determine the LA or drying in a oven to determine the DM. On the 
other hand, the leaf area is obtained through equations using simple variables such as length or width of leaves using indirect or non-destructive method (AQUINO et al., 2011).

However, it's necessary to carry out indirect method in order to fit mathematical models using regressions to determine these equations. There are studies in the literature for several crops, such as sunflower (AQUINO et al., 2011; LUCAS et al., 2015), banana (ZUCOLOTO; LIMA; COELHO, 2008), maize (MOKHTARPOUR et al., 2010), grape (MALAGI et al., 2010), potato (BUSATO et al., 2010; JADOSKI et al., 2012) and eggplant (HINNAH et al., 2014).

Therefore, the objective of this study was to define mathematical models, using linear measurements that estimate the area and dry matter of leaves of garlic plants - variety Ito, cultivated in the Alto Paranaíba - MG region.

\section{MATERIAL AND METHODS}

Fortnightly collections were carried out in agricultural fields in the Alto Paranaiba region $\mathrm{MG}$, at 1,143 m altitude. The climate is Cwa with two well defined seasons according to Köppen classification. The average annual temperature and precipitation are $20.5{ }^{\circ} \mathrm{C}$ and $1,512 \mathrm{~mm}$, respectively.
The garlic planting was carried out on April 12, 2014. The fertilization, commonly adopted in garlic fields in the Alto Paranaiba region, consisted of $250,1.000$ and $400 \mathrm{~kg} \mathrm{ha}^{-1}$ of $\mathrm{N}, \mathrm{P}_{2} \mathrm{O}_{5}$ and $\mathrm{K}_{2} \mathrm{O}$, respectively. The irrigation was performed using central pivot and the agricultural management according to the crop need.

Fifteen plants were collected, in each season at $30,45,60,75,90,115$ and 120 days after planting (DAP). The leaves of these plants were separated from the pseudostem, and the width and length were counted and measured using a millimeter ruler. The plants height $(\mathrm{H})$ was determined by measuring from the base of the plant close to the soil surface to the apex of the last leaf extended vertically. The pseudostem diameter (PD) was determined using a digital caliper, close to the soil surface, at the plants neck. The leaf area (LA) was measured by direct method using a Portable Area Meter LI-3000C. To determine dry matter (DM), the leaves were dried separately in a forced circulation stove oven at 70 ${ }^{\circ} \mathrm{C}$ during 72 hours and weighed with a precision analytical scale.

Regression analysis were performed between dependent variables (leaf area and leaf dry matter) and independent (length, width, length*width, pseudostem diameter, height and number of leaves) both for each sampling time and for all measures set of all sampling times (Table 1).

Table 1. Mean values of the total leaf area (TLA), individual leaf area (LA), length (L), width (W), dry matter $(\mathrm{DM})$, pseudostem diameter (PD), plant height $(\mathrm{H})$ and number of leaves per plant $(\mathrm{NL})$ for each sampling time of the variety Ito

\begin{tabular}{lllllllll}
\hline Time & $\begin{array}{l}\text { TLA } \\
\left(\mathrm{cm}^{2}\right)\end{array}$ & $\begin{array}{l}\text { LA } \\
\left(\mathrm{cm}^{2}\right)\end{array}$ & $\begin{array}{l}\mathrm{L} \\
(\mathrm{cm})\end{array}$ & $\begin{array}{l}\text { W } \\
(\mathrm{cm})\end{array}$ & $\begin{array}{l}\text { DM } \\
(\mathrm{g})\end{array}$ & $\begin{array}{l}\text { PD } \\
(\mathrm{mm})\end{array}$ & $\begin{array}{l}\mathrm{H} \\
(\mathrm{cm})\end{array}$ & $\begin{array}{l}\text { NL } \\
(\text { unit })\end{array}$ \\
\hline 30 & 100.24 & 22.78 & 23.44 & 1.21 & 0.68 & 6.47 & 38.51 & 4.40 \\
45 & 649.24 & 92.75 & 64.60 & 2.37 & 4.56 & 15.16 & 99.73 & 7.00 \\
60 & 509.02 & 69.44 & 57.30 & 2.19 & 4.00 & 13.65 & 92.39 & 7.30 \\
75 & 461.76 & 68.58 & 48.78 & 2.28 & 3.60 & 13.13 & 79.01 & 6.73 \\
90 & 443.97 & 62.83 & 51.44 & 2.12 & 3.37 & 13.38 & 75.20 & 7.07 \\
105 & 454.23 & 71.42 & 55.15 & 2.16 & 3.64 & 11.78 & 87.33 & 6.36 \\
120 & 529.74 & 67.82 & 54.53 & 2.13 & 4.28 & 12.10 & 82.87 & 7.81 \\
Mean & 457.49 & 67.96 & 53.18 & 2.13 & 3.53 & 12.36 & 81.43 & 6.73 \\
\hline
\end{tabular}

The coefficient of determination of linear regression $\left(\mathrm{R}^{2}\right)$, the root of the mean square error (RMSE), according to Janssen and Heuberger (1995), the modified concordance index (d1) proposed by Willmott et al. (1985) and BIAS index (LEITE; ANDRADE, 2002) were considered to determine the most representative models. The model is more representative with higher $\mathrm{R}^{2}$ and $\mathrm{d} 1$ values, lower RMSE values and BIAS index close to zero (RICHTER et al., 2014; TARTAGLIA et al., 2016). The equations were validated with significant constant and regression coefficient $\left(\beta_{0}\right.$ and $\left.\beta_{1}\right)$. Linear models were adjusted using the SigmaPlot 12.0 software. 


\section{RESULTS AND DISCUSSION}

The adjusted models showed differences in accuracy according to the time considered for the estimate (Table 2). In sunflower, changes in the leaf blade shape also altered the accuracy of the adjusted equations to estimate the DM or LA (AQUINO et al., 2011), similar to that obtained in the present study. The models to estimate LA and DM according to the Length $\mathrm{x}$ Width $\left(\mathrm{L}^{*} \mathrm{~W}\right)$ product showed the highest coefficients of regression and d1 values, as well the lowest RMSE values and BIAS index close to zero (Table 2). It occurs because the $\mathrm{L}^{*} \mathrm{~W}$ product results in the area value, which is the most similar to the LA, that is determined by destructive methods (TARTAGLIA et al., 2016). This same behavior is observed in several studies in different crops (ZUCOLOTO; LIMA; COELHO, 2008; BUSATO et al., 2010; AQUINO et al., 2011; JADOSKI et al., 2012).

Table 2. Mathematical models for estimating the leaf area (LA) of garlic $\left(\mathrm{cm}^{2}\right)$ as function of length (L), width (W) and length $\mathrm{x}$ width product $\left(\mathrm{L}^{*} \mathrm{~W}\right)$ with the respective statistical parameters: coefficient of correlation $\left(\mathrm{R}^{2}\right)$, root mean square error (RMSE), BIAS index and the modified concordance index (d1)

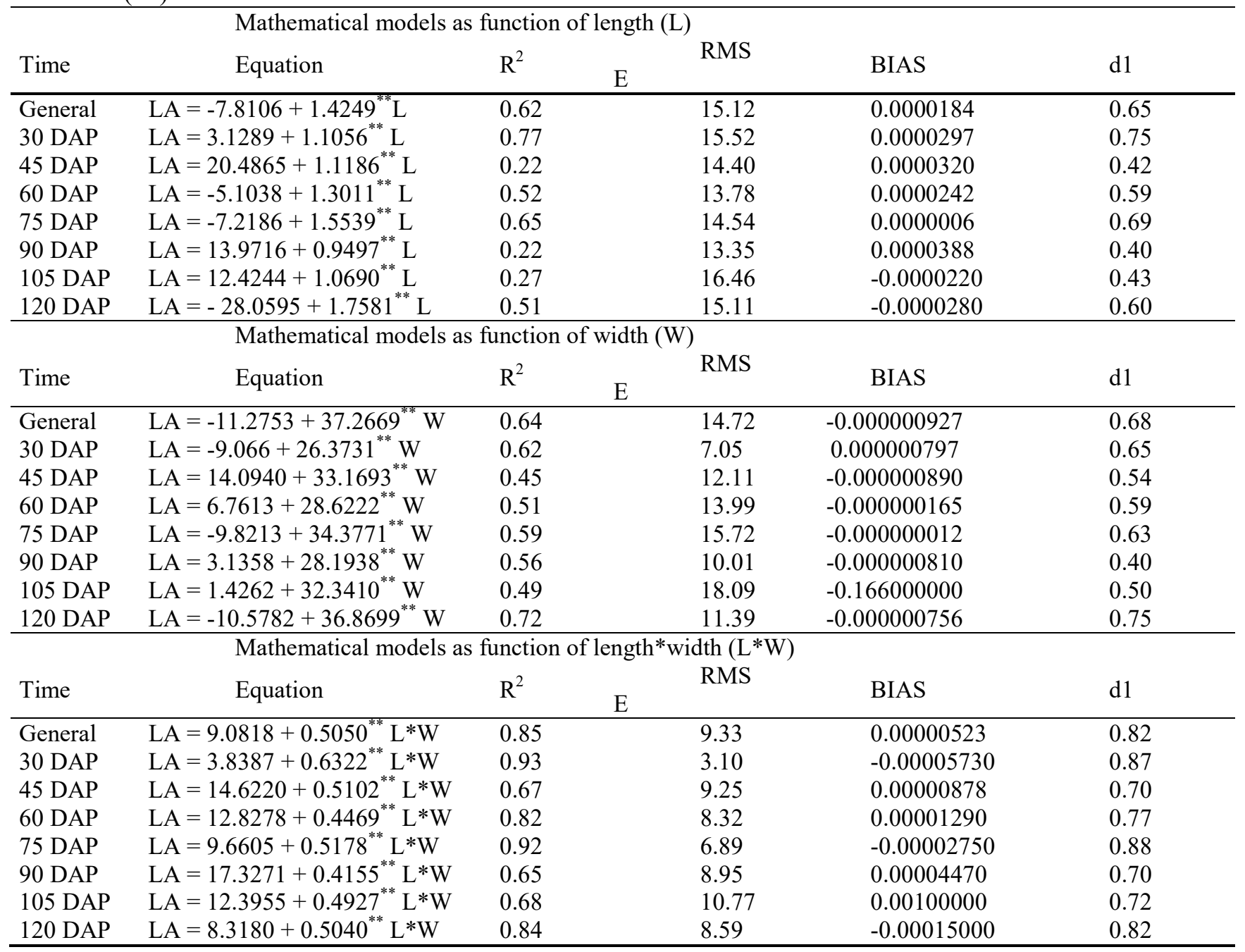

Models generated as function of only one variable, width or length, are more indicated for facilitating reviews (MALDANER et al., 2009). However, the predictions accuracy may be reduced when compared to models that consider the $\mathrm{L}^{*} \mathrm{~W}$ product due to variability of dependent variables ( $\mathrm{L}$ or W).
When only a linear measure of blade is considered, the models to estimate LA or DM as function of $\mathrm{W}$ were more accurate than L. It occurred with the adjusted models with all data set and those obtained separately with the measures times (45 DAP, 90 DAP, 105 DAP and 120 DAP Table 2). This result is similar to those obtained in sunflower (MALDANER et al., 2009; AQUINO et 
al., 2011) bean pod (TOEBE et al., 2012) persian walnut (KERAMATLOU et al., 2015), and canola (TARTAGLIA et al., 2016). However, Jadoski et al. (2012) obtained more accurate models when length was an independent variable to estimate the leaf area of potato. When the width is measured, the accuracy is lost due to leaflets movement, both inside and out, which produce different values. When the length is used, the measurement occurs on the main midrib of the leaf and the movement is lower.

The length and width presented average values of $53.18 \mathrm{~cm}$ and $2.13 \mathrm{~cm}$, respectively (Table 1). These values were close than those obtained by Rezende et al. (2013), with $47.8 \mathrm{~cm}$ length and 2.10 $\mathrm{cm}$ width for garlic leaves, variety Ito, in Guarapuava-PR.

There were differences among models. It is assigned to the format and number of leaves and total leaf area per plant in sunflower plants
(AQUINO et al., 2011). It is noteworthy, therefore, that mathematical models may differ depending on the experimental conditions, crop or even varieties. Nevertheless, these differences did not reduce the estimate accuracy of sunflower leaf area of varieties and different growing conditions, comparing the Maldaner et al. (2009) models with those obtained by Aquino et al. (2011).

Linear models were fitted for all times and data set in order to determine the leaf DM (Table 3). The models that showed the lowest RMSE values, BIAS index close to zero, higher index d1 values and coefficients of regression were those that used the $\mathrm{L}^{*} \mathrm{~W}$ product as an independent variable, as observed for LA. Cho et al. (2007) obtained models with coefficient higher than 0.80 for the same analyzed variables, and higher than 0.90 when the product of Length*Width*Spad was used, which is similar to the present study.

Table 3. Mathematical models to estimate leaf dry matter (DM) of garlic $\left(\mathrm{cm}^{2}\right)$ as function of length (L), width (W) and length $\mathrm{x}$ width product $\left(\mathrm{L}^{*} \mathrm{~W}\right)$ with the respective statistical parameters: coefficient of correlation $\left(\mathrm{R}^{2}\right)$, root mean square error (RMSE), BIAS index and modified concordance index (d1)

\begin{tabular}{|c|c|c|c|c|c|}
\hline \multicolumn{6}{|c|}{ Mathematical models as function of length } \\
\hline Time & Equation & $\mathrm{R}^{2}$ & RMSE & BIAS & $\mathrm{d} 1$ \\
\hline General & $\mathrm{DM}=-0.1090+0.0119^{* *} \mathrm{~L}$ & 0.62 & 0.13 & -0.00145 & 0.66 \\
\hline 30 DAP & $\mathrm{DM}=-0.0677+0.0095^{* *} \mathrm{~L}$ & 0.76 & 0.05 & 0.00290 & 0.75 \\
\hline 45 DAP & $\mathrm{DM}=-0.2366+0.0137^{* *} \mathrm{~L}$ & 0.42 & 0.11 & -0.00407 & 0.56 \\
\hline 60 DAP & $\mathrm{DM}=-0.1743+0.0126^{* *} \mathrm{~L}$ & 0.49 & 0.14 & -0.02800 & 0.57 \\
\hline 75 DAP & $\mathrm{DM}=-0.0964+0.0129^{* *} \mathrm{~L}$ & 0.64 & 0.12 & -0.00270 & 0.68 \\
\hline 90 DAP & $\mathrm{DM}=0.1060+0.0072^{* *} \mathrm{~L}$ & 0.19 & 0.11 & -0.00148 & 0.37 \\
\hline 105 DAP & $\mathrm{DM}=0.0113+0.0102^{* *} \mathrm{~L}$ & 0.35 & 0.13 & -0.00433 & 0.48 \\
\hline 120 DAP & $\mathrm{DM}=-0.3427+0.0163^{* *} \mathrm{~L}$ & 0.62 & 0.11 & -0.00344 & 0.67 \\
\hline \multicolumn{6}{|c|}{ Mathematical models as function of width } \\
\hline Time & Equation & $\mathrm{R}^{2}$ & RMSE & BIAS & d1 \\
\hline General & $\mathrm{DM}=-0.1132+0.3002^{* *} \mathrm{~W}$ & 0.59 & 0.131 & 0.00095 & 0.64 \\
\hline 30 DAP & $\mathrm{DM}=-0.1041+0.2139^{* *} \mathrm{~W}$ & 0.55 & 0.066 & -0.00024 & 0.61 \\
\hline 45 DAP & $\mathrm{DM}=-0.0812+0.2885^{* *} \mathrm{~W}$ & 0.47 & 0.130 & -0.07401 & 0.46 \\
\hline 60 DAP & $\mathrm{DM}=-0.0635+0.2783^{* *} \mathrm{~W}$ & 0.49 & 0.140 & -0.00004 & 0.58 \\
\hline 75 DAP & $\mathrm{DM}=-0.1101+0.2826^{* *} \mathrm{~W}$ & 0.57 & 0.130 & 0.00017 & 0.63 \\
\hline 90 DAP & $\mathrm{DM}=0.0005+0.2251^{* *} \mathrm{~W}$ & 0.53 & 0.085 & -0.00008 & 0.63 \\
\hline 105 DAP & $\mathrm{DM}=0.0321+0.2509^{* *} \mathrm{~W}$ & 0.42 & 0.120 & -0.00014 & 0.55 \\
\hline 120 DAP & $\mathrm{DM}=-0.0146+0.2646^{* *} \mathrm{~W}$ & 0.53 & 0.120 & -0.00011 & 0.62 \\
\hline \multicolumn{6}{|c|}{ Mathematical models as function of length*width } \\
\hline Time & Equation & $\mathrm{R}^{2}$ & RMSE & BIAS & $\mathrm{d} 1$ \\
\hline General & $\mathrm{DM}=0.0412+0.0042^{* *} \mathrm{~W}^{*} \mathrm{~L}$ & 0.82 & 0.088 & 0.0120 & 0.80 \\
\hline 30 DAP & $\mathrm{DM}=-0.0054+0.0053^{* *} \mathrm{~W}^{*} \mathrm{~L}$ & 0.89 & 0.033 & -0.0070 & 0.85 \\
\hline 45 DAP & $\mathrm{DM}=-0.0572+0.0046^{* *} \mathrm{~W}^{*} \mathrm{~L}$ & 0.70 & 0.079 & -0.0060 & 0.73 \\
\hline 60 DAP & $\mathrm{DM}=-0.0052+0.0044^{* *} \mathrm{~W}^{*} \mathrm{~L}$ & 0.80 & 0.088 & 0.0110 & 0.77 \\
\hline 75 DAP & $\mathrm{DM}=0.0496+0.0043^{* *} \mathrm{~W}^{*} \mathrm{~L}$ & 0.89 & 0.069 & 0.0085 & 0.92 \\
\hline 90 DAP & $\mathrm{DM}=0.1208+0.0033^{* *} \mathrm{~W}^{*} \mathrm{~L}$ & 0.59 & 0.079 & 0.0106 & 0.56 \\
\hline 105 DAP & $\mathrm{DM}=0.0765+0.0042^{* *} \mathrm{~W}^{*} \mathrm{~L}$ & 0.70 & 0.089 & 0.0064 & 0.72 \\
\hline 120 DAP & $\mathrm{DM}=0.0702+0.0040^{* *} \mathrm{~W}^{*} \mathrm{~L}$ & 0.77 & 0.086 & -0.0104 & 0.76 \\
\hline
\end{tabular}


The models, to determine the DM as function of only one variable, were determined as function of variance analysis of regression and linear coefficients $\left(\beta_{0}\right)$ and angle $\left(\beta_{1}\right)$ of regression, as well the $\mathrm{d} 1$ indices, RMSE and BIAS (Table 3). However, they showed less accuracy compared to the models that used the $\mathrm{L}^{*} \mathrm{~W}$ product.

Models fitted to estimate the total leaf area per plant (TLA) as function of the pseudostem diameter or height, considering all data set were obtained and showed good accuracy for estimating this growth variable (Table 4). However, it was not possible to fit models to estimate the TLA as function of the number of leaves, which is desirable due to its simplicity. Aquino et al. (2011) fitted models to estimate leaf area per plant as function of the number of leaves.

Table 4. Models for estimating the total leaf area (TLA) and total dry matter (TDM) of garlic plant $\left(\mathrm{cm}^{2}\right)$ as function of pseudostem diameter (PD) and plant height $(\mathrm{H})$

\begin{tabular}{lllll}
\hline Equation & $\mathrm{R}^{2}$ & RMSE & BIAS & $\mathrm{d} 1$ \\
\hline $\mathrm{TLA}=-141.6347+48.7996^{* *} \mathrm{PD}$ & 0.70 & 104.56 & 0.009000 & 0.67 \\
$\mathrm{TLA}=-183.1767+7.8674^{* *} \mathrm{H}$ & 0.71 & 92.02 & -0.000001 & 0.42 \\
$\mathrm{TDM}=-1.1649+0.3826^{* *} \mathrm{PD}$ & 0.68 & 0.86 & 0.009000 & 0.67 \\
$\mathrm{TDM}=-1.5344+0.0622^{* *} \mathrm{H}$ & 0.70 & 0.75 & -0.000300 & 0.70 \\
\hline
\end{tabular}

It was possible to fit models that use the neck diameter, and plant height as independent variables to estimate the dry matter of whole garlic plant (TDM - Table 4). In peach palm, Ramos et al. (2008) observed a relationship between leaf dry matter with height and diameter of the main stem. It's possible to estimate, accurately, the unit or total leaf dry matter of garlic plant using mathematical models that include variables such as length, width and pseudostem diameter.

RESUMO: Medidas de crescimento como área foliar (AF) e matéria seca (MS) são importantes em experimentos com população de plantas, adubação, irrigação e outros parâmetros de cultivo, na cultura do alho. Muitas vezes a AF e MS são definidas por avaliações destrutivas, demoradas e com perdas de plantas nas unidades experimentais. Objetivou-se, com este trabalho, definir modelos matemáticos através de medidas lineares, que estimem a área foliar e a matéria seca das folhas de plantas de alho da variedade Ito. Para isso, quinze plantas foram coletadas aos 30, 45, 60, 75, 90, 115 e 120 dias após o plantio (DAP). As medidas de largura (L), comprimento (C) das folhas, $\mathrm{AF}, \mathrm{MS}$, diâmetro do pseudocaule (DP), número de folhas por planta (NF) e altura da planta (AP) foram determinadas em cada época. Ajustaram-se modelos para estimar a AF ou MS em função das variáveis $\mathrm{L}, \mathrm{C}, \mathrm{L}^{*} \mathrm{C}, \mathrm{DP}$ e AF. Para determinar os modelos mais representativos foram verificados a análise estatística da regressão linear, o coeficiente de determinação da regressão linear $\left(\mathrm{R}^{2}\right)$, raiz do quadrado médio do erro (RQME), índice de concordância modificado (d1) e o índice BIAS. É possível estimar a AF e MS foliar de plantas de alho através das variáveis comprimento, largura, diâmetro do pseudocaule e altura de plantas.

PALAVRAS-CHAVE: Allium sativum L.. Alometria. Crescimento.

\section{REFERENCES}

ANAPA - Associação Nacional dos Produtores de Alho (2016) Alho Brasileiro; http://www.anapa.com.br/simples/?page_id=5.28 Ago. 2016.

AQUINO, L. A.; SANTOS JÚNIOR, V. C.; GUERRA, J. V. S.; COSTA, M. M. Estimates of sunflower leaf area by a non-destructive method. Bragantia, v. 70, n. 4, p. 832-836, 2011. http://dx.doi.org/10.1590/S000687052011000400015 
BUSATO, C.; FONTES, P. C. R.; BRAUN, H.; BUSATO, C. C. M. Evaluation of the potato plant leaf area, cultivar Atlantic, using linear measures. Revista Ciência Agronômica, v. 41, n. 4, p. 702-708, 2010. http://dx.doi.org/10.1590/S1806-66902010000400026

CHO, Y. Y.; OH, S.; OH, M. M.; SON, J. E. Estimation of individual leaf area, shoot fresh weight, and shoot dry weight of hydroponically growth cucumbers (Cucumis sativus L.) using leaf length, width, and SPAD value. Scientia Horticulturae, v. 111, n. 4, p. 330-334, 2007. http://dx.doi.org/10.1016/j.scienta.2006.12.028

CUNHA, M. L. P.; OLIVEIRA, T. F.; CLEMENTE, J. M.; GENTIL, T. G.; AQUINO, L. A. Modeling of nutrients demands in garlic crop. Australian Journal of Crop Science, v. 9, n. 12, p. 1205-1213, 2015.

HINNAH, F. D.; HELDWEIN, A. B.; MALDANER, I. C.; LOOSE, L. H.; LUCAS, D. D. P.; BORTOLUZZI, M. P. Estimation of eggplant leaf area from leaf dimensions. Bragantia, v. 73, n. 3, p. 213-218, 2014. http://dx.doi.org/10.1590/1678-4499.0083

JADOSKI, S. O.; LOPES E. C.; MAGGI, M. F.; SUCHORONCZEK, A.; SAITO, L. R.; DENEGA, S. Method of determination of the leaf area of the potato cultivar Ágata from linear dimensions. Semina: Ciências Agrárias, v. 33, n. 6, p. 2545-2554, 2012. http://dx.doi.org/10.5433/1679-0359.2012v33n6Supl1p2545

JANSSEN, P. H. M.; HEUBERGER, P. S. C. Calibration of processoriented models. Ecological Modelling, v. 83, n. 1-2, p. 55-66, 1995. http://doi:10.1016/0304-3800(95)00084-9

KERAMATLOU, I.; SHARIFANI, M.; SABOURI, H.; ALIZADEH, M.; KAMKAR, B. A simple linear model for leaf area estimation in Persian walnut (Juglans regia L.). Scientia Horticulturae, v. 184, p. 36-39, 2015. http://dx.doi.org/10.1016/j.scienta.2014.12.017

LEITE, H. G.; LIMA, V. C. A. A method for conducting forest inventories without using volumetric equations. Revista Árvore, v. 26, n. 3, p. 321-328, 2002. http://dx.doi.org/10.1590/S0100-67622002000300007

LUCAS, D. D. P.; HELDWEIN, A. B.; HINNAH, F. D.; MALDANER, I. C.; LOOSE, L. H. Estimation of leaf area index in the sunflower as a function of thermal time. Revista Ciência Agronômica, v. 46, n. 2, p. 404-411, 2015. http://dx.doi.org/10.5935/1806-6690.20150020

MALAGI, G.; CITADIN, I. SCARIOT, S.; REIS, L. Non-destructive method for leaf area determination of grapevine 'BRS-Violeta' cultivar. Revista Brasileira Fruticultura, v. 32, n. 4, p. 1250-1254, 2010. http://dx.doi.org/10.1590/S0100-29452011005000005

MALDANER, I. C.; HELDWEIN, A. B.; LOOSE, L. H.; LUCAS, D. D. P.; GUSE, F. I.; BERTOLUZZI, M. P. Models for estimating leaf area in sunflower. Ciência Rural, v. 39, n. 5, p. 1356-1361, 2009. http://dx.doi.org/10.1590/S0103-84782009000500008

MOKHTARPOUR, H.; TEH, C. B. S.; SALEH, G.; SELAMAT, A. B.; ASADI, M. E.; KAMKAR, B. Nondestructive estimation of maize leaf area, fresh weight, and dry weight using leaf length and leaf width.

Communications in Biometry and Crop Science, v. 5, n. 1, p. 19-26, 2010.

MORAVČEVIĆ, D.; BJELIĆ, V.; SAVIĆ, D.; VARGA, J. G.; BEATOVIĆ, D.; JELAČIĆ, S.; ZARIĆ, V. Effect of plant density on the characteristics of photosynthetic apparatus of garlic (Allium sativum var. vulgare L.). African Journal of Biotechnology, v. 10, n. 71, p. 15861-15868, 2011.

http://dx.doi.org/10.5897/AJB11.105

NGUY-ROBERTSON, A.; GITELSON, A.; PENG, Y.; VIÑA, A.; ARKEBAUER, T.; RUNDQUIST, D. Green Leaf Area Index estimation in maize and soybean: combining vegetation indices to achieve maximal sensitivity. Agronomy Journal, v. 104, n. 5, p. 1336-1347, 2012. http://doi:10.2134/agronj2012.0065 
OLIVEIRA, F. L.; DORIA, H.; TEODORO, R. B.; RESENDE, F. V. Agronomic characteristics of garlic cultivars in Diamantina, Brazil. Horticultura Brasileira, v. 28, n. 3, p. 355-359, 2010.

http://dx.doi.org/10.1590/S0102-05362010000300019

RAMOS, A.; BOVI, M. L. A.; FOLEGATTI, M. V.; DIOTTO, A. V. Leaf area and aboveground biomass estimates in peach palm using allometric relationships. Horticultura Brasileira, v. 26, n. 2, p. 138-143, 2008. http://dx.doi.org/10.1590/S0102-05362008000200002

REZENDE, J. T. V.; MORALES, R. G. F.; ZANIN, D. S.; RESENDE, F. V.; DE PAULA, J. T.; DIAS, D. M.; GALVÃO, A. G. Morphological characterization, commercial yield and productivity of garlic cultivars.

Horticultura Brasileira, v. 31, n. 1, p. 157-162, 2013. http://dx.doi.org/10.1590/S0102-05362013000100025

RICHTER, G. L.; ZANON JÚNIOR, A.; STRECK, N. A.; GUEDES, J. V. C.; KRAULICH, B.; ROCHA, T. S. M.; WINCK, J. E. M.; CERA, J. C. Estimating leaf area of modern soybean cultivars by a non-destructive method. Bragantia, v. 73, n. 4, p. 416-425, 2014. http://dx.doi.org/10.1590/1678-4499.0179

TARTAGLIA, F. L.; RIGHI, E. Z.; ROCHA, L.; LOOSE, L. H.; MALDANER, I. C.; HELDWEIN, A. B. Nondestructive models for leaf area determination in canola. Revista Brasileira de Engenharia Agrícola e Ambiental, v. 20, n. 6, p. 551-556, 2016. http://dx.doi.org/10.1590/1807-1929/agriambi.v20n6p551-556

TOEBE, M.; CARGNELUTTI FILHO, A.; LOOSE, L. H.; HELDWEIN, A. B.; ZANON, A. J. Leaf area of snap bean (Phaseolus vulgaris L.) according to leaf dimensions. Semina: Ciências Agrárias, v. 33, n. 6, p. 2491-2500, 2012. http://dx.doi.org:10.5433/1679-0359.2012v33Supl1p2491

WILLMOTT, C. J.; ACKLESON, S. G.; DAVIS, J. J.; FEDDEMA, K. M.; KLINK, D. R. Statistics for the evaluation and comparison of models. Journal of Geophysical Research, v. 90, p. 8995-9005, 1985. https://doi.org/10.1029/JC090iC05p08995

ZUCOLOTO, M.; LIMA, J. S. S.; COELHO, R. I. Esteem method of total leaf area of 'Prata anã' banana tree. Revista Brasileira de Fruticultura, v. 30, n. 4, p. 1152-1154, 2008. http://dx.doi.org/10.1590/S010029452008000400050 